\title{
Back to Sendangsono
}

\section{A Marian Pilgrimage Site as a Lens on Central Javanese Cultural Values*}

\author{
Herman L. Beck \\ Tilburg University \\ h.l.beck@uvt.nl
}

\begin{abstract}
Sendangsono is by far the most popular place of pilgrimage for Roman Catholics in Indonesia. It has been known from time immemorial as a centre of worship of indigenous religions. However, during the first three decades of the twentieth century the Roman Catholic missionaries Van Lith and Prennthaler succeeded in turning it into a Christian pilgrimage centre focused on the devotion to Maria. By applying the principles of adaptation and inculturation these Jesuit priests turned the place into a West European Christian stronghold amid a hostile, 'pagan' environment. However, since the late fifties of the twentieth century a kind of 'Javanization' of this Marian pilgrimage site seems to have taken place. The author, architect, and priest Yusuf Bilyarta Mangunwijaya played a crucial role in this process. Partly due to his efforts, Sendangsono became the place where Javanese believers of all persuasions celebrate their 'shared Javanese cultural values as a Common Bond'.
\end{abstract}

\section{Keywords}

ritual - shared sacred places - religious diversity - Javanization

* This contribution is a thoroughly revised and elaborated version of my 2015 article in a Festschrift dedicated to Walter van Beek and published in in a very limited edition.

I wish to thank the two anonymous reviewers for providing valuable comments on the draft.

(C) HERMAN L. BECK, 2018 | DOI:10.1163/22134379-17401023

This is an open access article distributed under the terms of the prevailing CC-BY-NC license 


\section{Introduction}

Early in the afternoon of Sunday, 11 January 2015, I arrived at the Sendangsono car park. Sendangsono is the oldest and most famous Our Lady of Lourdes pilgrimage site in Indonesia. It was my first visit to Sendangsono since 1993 . To my recollection, the 32-kilometre journey from the centre of Yogyakarta to Sendangsono, which belongs to the municipality of Kalibawang in Bukit Menoreh (the Menoreh Hills) of Central Java, used to take much more of an effort. The road from Yogyakarta to Sendangsono is much better now than it was 22 years ago, when I made the journey on the back of a friend's moped and felt every hole in the road, which was in a bad state of repair. It was only during the 198 os that this pilgrim site was made accessible for motorized traffic (Antono 2011:223). That friend came from a Javanese family living in the countryside near Yogyakarta; almost every member of the family practised a different religion. The parents were Hindus, some children had become Muslims, while other children had opted for Roman Catholicism or had remained true to their parents' religion. My friend became a Roman Catholic because she had been educated at a Roman Catholic school.

My friend mentioned various reasons why I should come with her to Sendangsono. As the oldest and most famous Our Lady of Lourdes pilgrimage site in Indonesia, Sendangsono played an important devotional-spiritual role in the lives of Roman Catholics in Central Java. Moreover, since it is an area of great natural beauty, Sendangsono was a highly suitable destination for a relaxing day out. As a third reason, she mentioned the fact that Sendangsono was interesting because it was also visited by Muslims and other non-Catholic Javanese. That latter motive inspired me to write an article about the Muslim perspective on Our Lady of Sendangsono (Beck 1995:203-231). In that article, I concentrated on the worries of modernist Muslims in the Muhammadiyah movement who feared that visiting such a Roman Catholic pilgrimage site dedicated to Mary might be attractive to uneducated fellow believers with little knowledge of their own religion, and might lead them to thoughts and actions inconsistent with orthodox and orthoprax Islam.

\section{Focus and Central Question}

This time I wanted to go back to Sendangsono because I was puzzled by the question of whether and, if so, with what result Sendangsono as a pilgrimage site can serve as a lens through which to observe the surrounding Central Javanese culture and its values and norms. This leads to the following research 
question for this article: what can be said about the Central Javanese cultural values of the Provinsi Daerah Istemewa Yogyakarta (Special Region of Yogyakarta) when perceived through the lens of the pilgrimage site at Sendangsono?

From the car park, I headed to the Our Lady of Lourdes grotto of Sendangsono. It is only around five hundred metres from the small car park to the Our Lady of Lourdes grotto at Sendangsono. First I passed under a gate that had not yet been built in the early 199os but was completed in 2007, and I followed the road that was lined with the familiar shops and warung, the eating houses that are omnipresent in Central Java around cultural attractions, places of pilgrimage, and monuments like Borobudur and Prambanan. A relatively large number of the shops specialized in Marian devotional items. In the early 199os, this trade had not yet become prominent. Furthermore, the shops were in good repair and the street was well paved, while in the early 199os it was still a dirt road and the shops looked shabby. I entered several of the shops to look at the replica statues of Our Lady; some were as tall as I was, or even taller, and some were small, while others could serve the purpose of a bidon. On closer inspection, most of these devotional items proved to have been made in China. They were no different from the Chinese products sold in Lourdes or at any other Marian shrine anywhere in the world. Thus, the Marian shrines are linked not only because of Our Lady, but also because of the devotional items on sale at the site originating from China.

This 'global interconnectedness' of Marian shrines brings to mind the three women - a mother and her two daughters-from Jakarta whom I met in the Netherlands in 2013. They had come to Europe to visit some of the most important Catholic shrines, naturally including famous Marian shrines like Lourdes, Fatima, and Banneux. When I asked them whether they had been to Sendangsono, they answered that the Our Lady of Lourdes grotto in Sendangsono had naturally been the starting point of their pilgrimage expedition. Their reaction seemed to imply that for them, as Indonesian Roman Catholics, Sendangsono formed part of a worldwide network of shrines dedicated to Our Lady. ${ }^{1}$ A tangible physical and spiritual bond between Lourdes and Sendangsono had already been forged by a group of students who visited Lourdes in 1954 to celebrate the centenary of the Feast of the Immaculate Conception. The students brought back from Lourdes a stone on which Mary allegedly stood

1 After the three ladies had returned to Indonesia, they sent me a printed booklet composed by themselves and published on their own consisting of the prayers and songs they had performed at all the Marian shrines they had visited, both in Indonesia and in Europe. 
when she appeared to Bernadette Soubirous and, in 1956, they placed the relic at the feet of the statue in the grotto at Sendangsono (Ziarah ke Gua Maria 2010:29).

Having passed the shops and warung, I crossed a small bridge and an open space and came to the stairs that I needed to descend in order to get to the site of the Our Lady of Lourdes grotto. At the top of these stairs is a sign, requesting visitors to observe silence from this point because it is a sacred place. At the foot of the stairs is an open space between the statue of Our Lady in the Lourdes grotto and two huge trees. Twelve people were seated on low stools or cross-legged on the ground, absorbed in prayer or meditation. Now and then someone lighted a candle and placed it before the statue of Our Lady in the grotto. In 2008, this grotto was restored to its original state of 1929 (Ziarah ke Gua Maria 2010:65). A few steps lower down, another two men were praying, sitting cross-legged in front of the spring in which the first inhabitants of Kalibawang had been baptized. The reason for the limited number of pilgrims on this particular Sunday was that the pilgrimage season at Sendangsono does not officially start until 11 February. Things will certainly be different in the months of May and October: the crowds of pilgrims will be so large that as many as fifteen masses will have to be celebrated every Sunday (Sindhunata 2004:68). The oldest documentation of the number of pilgrims visiting Sendangsono in the month of May dates from 1957, when an estimated 50,00o people came to the place (Antono 2011:223).

At this point, it is necessary to pay attention to the history of the Our Lady of Lourdes grotto at Sendangsono in order to understand in what way this Marian pilgrimage site can serve as a lens on Central Javanese cultural values.

\section{Establishment and Development of the Our Lady of Lourdes Grotto at Sendangsono as a Pilgrimage Site: The Master Narrative ${ }^{2}$}

From a religious point of view, Sendangsono has of old been a special place. The name Sendangsono is a combination of the two Javanese words sendang (spring, small lake) and sono or sana (a type of tree [waringin or ficus]), and means something like 'the spring of the waringin'. In non-Muslim and nonChristian Javanese religious perceptions, both springs and trees are considered

2 The following section is the English translation of the thoroughly revised and elaborated version of Beck 1995:205-13. Compare also with Courtens 2009:101-15 and Laksana 2014:11221. 
to be the haunts of nymphs and other supernatural beings (Kruijt 1906:504). Such sites, therefore, easily develop into places of pilgrimage.

\section{Sendangsono Before the Arrival of the Jesuit Missionaries}

Sendangsono was one of three springs in the water-scarce part of the Menoreh Hills in the Kalibawang area. The majority of the people of Kalibawang are Muslim but, in their day-to-day lives, most of them hold on to religious perceptions and religious practices not belonging to 'orthodox and orthopractical' Islam. A case in point is the role that the spring and the two ficus trees play in their lives. Before the spring became a Christian site, following Father Van Lith's dedication in 1904, both the spring and the two waringin were closely associated with the goddess Dewi Lantamsari. Although she had remained a virgin, Dewi Lantamsari had a son, called Raden Bagus Samijo, commonly known as Den Baguse Samijo. He and his mother inhabited and protected the spring and the two waringin (Fanani 1985:35). This was the reason, according to the people of Kalibawang, that the spring water had magical powers and brought luck (Soeradjiman 1976:33).

The spring was also very important for teachers of the ilmu ghaib (secret knowledge, gnosis, mysticism). They used the water of Sendangsono when teaching their followers. For instance, the ritual ablutions of the adepts of the secret knowledge taught by Pak Grudug, called Dawud Tadikromo after he converted to Christianity, took place at the spring. The spring was also important to ascetics who engaged in their exercises there. In pre-Islamic times, Sendangsono was a resting place for Buddhist monks, who halted at this spring - located halfway between the Borobudur temple and their monastery in Bara-to rest and refresh themselves in its waters. Moreover, Sendangsono was visited annually by people in the region, who swore their oaths there, made promises, brought sacrifices, and held slametan (joint, ritual meals), to placate and honour the local gods and spirits. Furthermore, dicing took place at the spring and dancing girls, who were also prepared to provide other services, gave performances there (Soeradjiman 1976:34-6). ${ }^{3}$ These religious practices and other customs continued to exist, despite the Islamization that gained momentum in this part of Central Java in the seventeenth century under the Muslim Mataram dynasty.

In the nineteenth century, Dutch Protestant missionaries attempted to Christianize Central Java. Initially, the Javanese seemed to take to Protestantism under the guidance of Sadrach. Sadrach (d. 1924), a Muslim who had convert-

3 For the gamblers and the 'dancing girls', see Koentjaraningrat 1985:200. 
ed to Christianity, felt that Christianity and Javanese adat (local customary law) were not incompatible. In his opinion, Christians in the closed, largely Muslim rural community of Central Java, where life as a member of the community is central and where one good turn always deserves another, cannot exclude themselves by avoiding compliance with adat (Sutarman 1990:58, 132, 145). Sadrach's view was adopted by the Javanese, but was unacceptable to most Dutch missionaries. They wanted the Javanese to model their lives on the Dutch ideal of the typical Protestant Christian. As a result of this rigid point of view, and the mission's overbearing attitude towards Sadrach and other prominent Javanese Christians, Protestantism lost much of its appeal and most of its members, including the above-mentioned Dawud Tadikromo (Van Lith 1930:256, 258).

\section{Sendangsono and the Jesuit priest Frans van Lith (1863-1926)}

The Roman Catholic mission in this part of Central Java was based in the town of Muntilan. One of the Catholic missionaries, the above-mentioned Jesuit priest Frans van Lith $\left(1863^{-1926)}\right.$ from Oirschot in the Netherlands, worked indefatigably for the Christian faith (Van Rijckevorsel 1952; Steenbrink 2007:370-405; Kruithof 2014:96-8, 352-66). Van Lith knew Sadrach personally (Sutarman 1990:143). Because he visited Sadrach at his home and attended meetings led by Sadrach, Van Lith knew his views on what would now be called the 'inculturation' of Christianity. ${ }^{4}$ Van Lith's own missionary methods may have been influenced by Sadrach's conflict with the Protestant mission. Whatever the case may be, Van Rijckevorsel summarizes Van Lith's approach as follows: 'Father Van Lith applied the two important principles of adaptation and elite formation. Adaptation to the nature and needs of the Javanese in those days; elite formation, that is to say: the cultivation of powerful men, leaders' (Van Rijckevorsel 1952:77).

Van Lith seems to have used the principles of adaptation and elite formation in the Christianization of Kalibawang and the surrounding area. With regard to elite formation, it is interesting to note that Dawud Tadikromo, the former secret-knowledge guru and Sadrach's former pupil, was indirectly involved in winning a powerful man for the Christian faith. It was he who brought Barnabas Sarikromo, the later catechist of Kalibawang - who received the papal medal of honour Pro Ecclesia et Pontifice for his lifelong missionary efforts in 1929 (Vriens 1930a:108)—into contact with the Jesuits in Muntilan. When Dawud Tadikromo was a secret-knowledge guru, Barnabas Sarikromo had sought his

4 On the use of the concept of 'inculturation', see, for instance, Roest Crollius 1984. 
help to cure his seriously injured foot. At first, Dawud Tadikromo had given him an ointment, but he also advised him to have his foot regularly treated by the Jesuits in Muntilan, where he had procured the ointment. After some time, Barnabas Sarikromo became so interested in the church that he began to attend the Sunday services. Finally, on 20 May 1904, he was the first Catholic in Kalibawang to be baptized by Father Van Lith. After further education, he developed into a successful local catechist, who devoted his life to preaching the Christian gospel in this region (Soeradjiman 1976:16-20). As an inhabitant of Kalibawang and former student of the secret knowledge, Barnabas Sarikromo was well placed to advise Van Lith on the strategy to be adopted in the Christianization of this part of Central Java. The same was true of Dawud Tadikromo himself, who told Van Lith that he wanted to become a Catholic and, in the presence of four village chiefs, also informed him that a number of people from Kalibawang and the surrounding area were prepared to become Catholics (Van Lith 1930:258). Some time later, Van Lith, Dawud Tadikromo, and Barnabas Sarikromo visited the villages of the four chiefs, namely Kajoran Wetan (Lukas Suratirta), Kajoran Kulon (Markus Sukadrana, Lukas's brother), Semagung (Abraham Dipadangsa), and Tuksångå (Jokanan Surawidjaja) (Soeradjiman 1976:23-25). During Van Lith's first journey around the Kalibawang area, Dawud Tadikromo informed him about the local customs and practices, and thus prevented Van Lith from behaving in ways that the people or their chiefs might consider improper or offensive (Van Lith 1930:289-91).

In his posthumously published notes about this tour of the villages in Kalibawang, Van Lith explicitly mentioned the spring at Sendangsono near the hamlet of Semagung (Van Lith 1930:293):

We then came to ancient Semagung and, as the first Catholic priest ever, I stood on the spot where, a few months later, I was to baptize the first 200 people from Kalibawang, in the same spring where formerly Buddhist monks in their yellow robes used to quench their thirst on their journey from one Båra to the other.

However, before Van Lith baptized the villagers of Kalibawang at Sendangsono spring on 14 December 1904, ${ }^{5}$ he baptized Barnabas Sarikromo and Dawud Tadikromo as well as the four village chiefs-Lukas Suratirta, Markus Sukadrana, Abraham Dipadangsa, and Jokanan Surawidjaja—on Whitsun (2o May 1904). The Christianization of the Kalibawang area clearly shows that Van Lith indeed practised the principle of elite formation.

5 Incidentally, although Van Lith mentions 200 people, other sources state a number of 171 or 
That Van Lith applied the principle of adaptation of the Catholic faith to the nature and needs of the Javanese in those days is clear from his choice to place a statue of the Virgin Mary at the Sendangsono spring, and the subsequent development of the site as the 'Lourdes of Indonesia'. Given the quotation in the previous paragraph, Van Lith immediately realized that the spring at Sendangsono had a special religious significance for the people in the area. In the months between his first visit to Sendangsono and the baptism of the 173 villagers with water from the spring he had previously dedicated, Van Lith may have made further inquiries among the recently baptized leaders as regards the religious perceptions of the local people. That Van Lith chose a statue of the Virgin Mary to be placed at the spring, removing her nonChristian connotations and thus safeguarding her future from all forms of traditional, non-Christian religious perceptions, may be connected with the date on which he administered the baptism. The 8 December 1904 marked the 5oth anniversary of the proclamation of the dogma of the Immaculate Conception of Mary. The baptismal ceremony at the spring took place six days later, on 14 December 1904. Van Lith may have chosen to install the statue of Our Lady to commemorate the proclamation of the dogma. This would be consistent with the Marian devotion that had been prevalent since the second half of the nineteenth century, and was considered to be a viable missionary method. With this choice, he may have taken into account the religious perceptions of the local Javanese population concerning the virgin goddess Dewi Lantamsari and her son Den Baguse Samijo. ${ }^{6}$

Other considerations may also have played a role for Van Lith. He knew how important growing rice, maize, cassava, and fruit like mangoes was to the people in this region (Van Lith 1930:294) and, consequently, what meaning they attached to fertility. Since he was knowledgeable about the Javanese language and culture, he was aware of what Dewi Sri stood for (Madinier 2011:3). In Hinduism, Dewi Sri, also called Lakshmi, is the goddess of vegetation, fertility, prosperity, and wealth. She is also the wife of the supreme god Vishnu and the mother of all creatures (Appel 1991:28). In Javanese religious perceptions, Dewi Sri continues to function as the goddess of fertility and rice. Finally, in

173. See for instance Heuken S.J. 1989 s.v. 'Sendangsono': 171 people; Soeradjiman (1976:35): 173 people.

By way of comparison, it is worth noting that, according to the Encyclopaedie van Nederlandsch-Indië, second edition, s.v. 'Kalibawang', the number of inhabitants of Kalibawang in 1905 was estimated to be 27,000 .

6 In the multitude of publications on the subject, a good starting point for studying Marian devotions is Beinert and Petri 1984. 
Javanese folklore, Dewi Sri is one of the heavenly nymphs that are associated with water, vegetation, and fertility. As a heavenly nymph, Dewi Sri is known for her kindness and benevolence. She protects the home, the hearth, and children and provides guidance and assistance in difficult situations. People bring all kinds of sacrifices to Dewi Sri, and she rewards them with honour, prosperity, and a long life (Appel 1991:29-31). Although Van Lith has never, to my knowledge, explicitly stated it, it is possible that, in this rural community where women played such an important economic role (Boelaars 1984:93), he saw so many connections between Dewi Lantamsari, Dewi Sri, and Mary, that he considered the latter to be an excellent channel, via associations of religious perceptions, to gradually make the inhabitants of the Kalibawang area familiar with the Catholic faith. In addition, Van Lith may have sought to make links with the ideas in Islam with respect to Mary (in Arabic: Maryam). Given the Muslim reverence for Mary as the mother of Jesus, Van Lith may have believed it suitable to introduce her in the religious lives of the Javanese Muslims.

As a result of his many other activities, Van Lith was not able to be actively involved in developing the Catholic faith in the Kalibawang area after the baptismal ceremony. He did, however, help Barnabas Sarikromo in 1914 to set up a popular missionary school, first in Sarikromo's own home and, in 1919, in a larger building close to Sendangsono. This new building also served as a church (Soeradjiman 1976:28). Through Barnabas Sarikromo, Van Lith continued to be involved in Kalibawang and was able to give advice on missionary tactics. Being native to Kalibawang, catechist Barnabas Sarikromo was aware of the locals' need for entertainment and recreation in the traditional holidays. He knew that, on these occasions, they loved to hear gamelan music and enjoyed the selawatan, the Islamic performances consisting of prayers and stories about important events in Islam and in the lives of the prophets. Sarikromo wanted to make use of the fondness of the Kalibawangese for these forms of entertainment for the purposes of the Catholic faith and informed Van Lith to this effect. Van Lith then ordered some Javanese staff members to create 'Catholic selawatan' based on stories from the Old and New Testament and the catechism. He also commissioned research into the suitability of other forms of Javanese art and music for missionary purposes (Soeradjiman 1976:29).

\section{Sendangsono and the Jesuit priest J.B. Prennthaler (1885-1946)}

As we have seen, Van Lith was clearly alert to the importance of adapting the Catholic faith to the mind and needs of the Javanese. Placing a statue of the Virgin Mary near a spring that had traditionally been linked to Javanese religious perceptions concerning vegetation, fertility, prosperity, wealth, spirits, the vir- 
gin goddess Dewi Lantamsari and her son Den Baguse Samijo, and Dewi Sri as a heavenly nymph and mother of all creatures, may therefore be interpreted in light of the adaptation strategy referred to above. However, the person who promoted Mary even more convincingly and used the fact that Sendangsono, as a place of pilgrimage, had long had a certain appeal for the inhabitants of Central Java, was J.B. Prennthaler (1885-1946). In 1923, this Austrian Jesuit priestpastor of the neighbouring village of Mendut - was also responsible for the pastoral care of Kalibawang (Van Lith 1930:293). Prennthaler was of the opinion that visitors would continue to associate Sendangsono with the old types of 'superstition' and a belief in all sorts of spirits. Therefore, he intended to change the character of the place by erecting a larger-than-life-sized statue of Mary of the Immaculate Conception in a specially built Lourdes grotto, which would function as a refuge for people from Kalibawang seeking protection (Soeradjiman 1976:36). The Lourdes grotto could be constructed thanks to a financial donation from the congregation of St Canisius in Maastricht, the Netherlands, while the large statue of Mary Immaculate, weighing 300 kilogrammes, was sent to Central Java as a gift from an anonymous benefactress in Europe (Vriens 1930a:98). ${ }^{7}$

It is impossible to establish what inspired Van Lith to place the statue of Our Lady near the spring, and it is similarly hard to determine why Father Prennthaler opted precisely for Mary Immaculate and the Lourdes grotto associated with her. Did Prennthaler have thoughts similar to Van Lith's, that is, that Mary, on the one hand, as a mother and as a giver of fertility, wealth, and prosperity paralleled Javanese religious perceptions concerning Dewi Lantamsari and Dewi Sri and, on the other hand, that her immaculate conception completely corresponded with the Muslim view of the mother of Jesus and with the respect in which she is held in this religion? On Mary as a mother, all manner of expectations could be projected that the faithful would also attribute to the ideal mother, who always answers the supplications of her children (Tennekes 1986:8). Mary's immaculate conception could be considered a stimulus for Muslims to change faith. In short, in Prennthaler's view, Mary may have formed the ideal identification object for Javanese Muslims. The devotional, ritual opportunities offered by Sendangsono as a pilgrimage site may equally have been an important motivation for him to choose this particular spot: a replica of

7 In the literature, there is some doubt as to the European country from which the statue of the Virgin Mary originated. Courtens (2009:108) argues, on the authority of Ludovikus Wiryanto, the son of Barnabas Sarikromo, that the statue is from Denmark. This country is also mentioned in Sindhunata (2004:15). According to Ziarah ke Gua Maria (2010:10) and 85 tempat ziarah (2013:16), the statue originates from Switzerland. 
the Lourdes grotto might have a similar appeal to that of the original. Lourdes's popularity - everything that happens there can also be experienced right here at home in Central Java, with no need to embark on a long, costly, and dangerous journey-combined with Sendangsono's traditional pilgrimage practices could attract many believers and sightseers. Subsequently, Catholic pilgrimages would slowly but surely push the old religious perceptions connected to previous pilgrimages to the spring into the background until ultimately they would be entirely eliminated. Also through the installation and the ringing, three times a day, of the Angelus bells - a rather bold step in an Islamic environment, where the faithful were called to prayer five times a day-Prennthaler hoped to achieve that 'the cheerful ringing of the bell would open all Javanese hearts to the grace and the love of the Heavenly Mother, who is also given to them as a Mother!' (Rood 1930:123; compare also with Courtens 2009:109 and Laksana 2015:109)

Whatever the considerations, Prennthaler dedicated the Lourdes grotto and the Mary Immaculate statue on 8 December 1929, exactly 75 years after the dogma of the Immaculate Conception of Mary had been proclaimed. That day was also the 25th anniversary of the Kalibawang mission, and therefore Barnabas Sarikromo's silver anniversary as a catechist as well (Vriens 1930a:98). The words that, according to Vriens, Prennthaler spoke when he dedicated the Lourdes grotto and the Mary Immaculate statue at least partly revealed his intentions:

When everyone, approximately 700 people [...], had assembled in front of the grotto, P. Prennthaler S.J., the current shepherd of Kalibawang, addressed his flock [...] He reminded them that the spring of Sendang Sånå, welling up at his feet, had long been considered a special place because - it was believed - it housed devils and evil spirits, which had to be placated by offerings and sacrifices. Fortunately, this spring had later been used to baptize people. Now all those gathered, strengthened by baptism and enlightened by faith, knew that there are no evil spirits in Sendang Sånå. And the devil? Yes, he had dwelt here in earlier times, when the village was a notorious haunt of gamblers and dancing girls. But that was in the past! Here, too, Mary, through whose intercession they had obtained all graces, had crushed Satan's head. To show their great gratitude, they had built their grotto, which was to be solemnly consecrated today. Finally, the reverend urged everyone to come frequently to the grotto of Sendang Sånå to pray, to thank God and Mary for all the benefits they bestowed, and also to unburden their hearts.

VRIENS 193Oa:102-3 
In his account of this ceremony, Soeradjiman states that Prennthaler admonished those present not to expect a miracle from God or an apparition of Mary. They should merely request Mother Mary to protect the community of Kalibawang as a whole, and in particular its Catholic inhabitants and the pilgrims journeying to this place. To that end, they should all undertake a pilgrimage to this place to thank God through Mary for all good things (Soeradjiman 1976:38). Prennthaler thus not only considered Mary's presence as banning all evil aspects of a pre-Christian, 'superstitious' belief in spirits and devils, but also as providing all that is good because of her intercessory role with God. By making a pilgrimage to Sendangsono, the faithful can address Mary in her position of mediator. The fact that Van Lith and Prennthaler made Mary central to the religious practice of Sendangsono seems to have resonated well with the Javanese of Kalibawang and the surrounding area from the very beginning. After all, as stated in the quote above, 700 people graced the dedication and blessing of the spring and the Mary Immaculate statue with their presence. Seven months later, on Sunday, 13 July 1930, the number of those attending a Catholic religious ceremony in Sendangsono was even larger. The occasion involved a procession celebrating the 'Blessed Sacrament of the Altar': 45 o school children and 1300 adults from Kalibawang are said to have participated. Moreover, 300 Catholic Javanese from various Central Javanese towns were present, but it was also stated — not without pride - that 8o Europeans, including five people hailing all the way from Surabaya, 3 o soldiers headed by an army chaplain, and Professor Brom and his wife from Nijmegen, the Netherlands, attended (Vriens 1930b:232-8). In the eyes of many Javanese, the interest shown, and the actual participation of various prominent non-Javanese, considerably increased Sendangsono's prestige as a place of pilgrimage and boosted its popularity.

In the years after the dedication of the Lourdes grotto with the Mary Immaculate statue, the religious structure of Sendangsono as a pilgrimage site was further enhanced. In 1940, building work started on the Our Lady of Lourdes Church in Promasan (Kalibawang) (Soeradjiman 1976:47). This Westernstyle building forms the starting point for pilgrims who journey to Sendangsono via the Way of the Cross, with fourteen stations completed in 1958 (Soeradjiman 1976:42). The annual procession on 11 February, which marks the beginning of the pilgrimage season, also starts at the church of Promasan (Soeradjiman 1976:48). In the Marian year 1954, a chapel and a main altar were dedicated in Sendangsono, so that pilgrims would be able to celebrate the Eucharist (Rzepkowski 1991:301). Also, spaces for overnight stays and little restaurants were realized to accommodate the growing numbers of pilgrims. 
History has shown that Van Lith's and Prennthaler's missionary strategy of adaptation and elite formation among Javanese Muslims has been successful. In 1904, Van Lith baptized 173 people from Kalibawang, that is, approximately o.6\% of the local population; in 1976, the number of Catholics in this area was estimated at approximately 10,00o (Soeradjiman 1976:48). In 1990, up to $30 \%$ of the people in some hamlets belonging to Kalibawang were Roman Catholics, whereas in Indonesia as a whole only $3 \%$ of the population is Roman Catholic (Suparyanto 1990:19). ${ }^{8}$ In Van Lith's and Prennthaler's conversion strategy, great importance was attributed to Mary. Whether deliberate or intuitive, the choice to build an Our Lady of Lourdes grotto that developed into a Marian pilgrimage site was a fortunate one. It did not only mesh well with pre-Islamic and preChristian Javanese religious perceptions and practices, but also with religious perceptions and practices in Islam.

\section{New Emphases in the 'Master Narrative'}

\section{Barnabas Sarikromo (1874-1940) and the further Javanization' of Sendangsono}

Exploring the Sendangsono complex, I was struck by the sight of something I do not remember having seen in 1993: a large tomb with the text 'Barnabas Sarikromo, the first catechist of Kalibawang, died 15 July 1940; [and his wife] Adriana Sarikromo, died 6 May 1966'. Behind this huge memorial are more, but very simple graves of other Javanese people who worked as catechists in the Kalibawang area. Upon inquiry it appeared that in the past this area was the village cemetery, but now the graveyard had become an integral part of the pilgrimage complex. In the course of the mid 199os, the grave of Barnabas Sarikromo and his wife was singled out to be restored and to be transformed into a rather 'Western', pompous memorial. The initiative to restore Barnabas Sarikromo's grave was taken by the local community in remembrance of his meritorious services. The model of the grave was designed by Brother Yanto, who was a pastoral worker in the Promasan parish, and the activities were supervised by Father Tukirman, the parish priest of Sendangsono at that time. ${ }^{9}$

Not only this huge memorial of Barnabas Sarikromo and his wife, but also the three booklets that I bought in a warung close to the graveyard seem to

8 Suparyanto (1990:19) states that in 1990 the village of Banjaroya had a total population of 8,372: 5,757 Muslims, 2,599 Roman Catholics, and 16 Protestants. For figures relating to the religions, see Boelaars (1991:153-55).

9 I owe this information to Father Herman Sanusi and Father Max Regus. 
reveal that new accents have been added to Sendangsono's 'master narrative'. The three booklets were recently published: the first one in 2004, to commemorate the centenary of the baptism of the first people from Kalibawang at Sendangsono (Sindhunata 2004); the second in 2010, as a kind of manual and historic guide on pilgrimages to Sendangsono (Ziarah ke Gua Maria 2010); and the third, published in 2013, which discusses Sendangsono as the place of pilgrimage with the oldest Our Lady of Lourdes grotto of the 85 pilgrimage sites now existing in Indonesia, according to its author (85 tempat ziarah 2013). In these three booklets there seems to be more of a focus on the role and input of the Javanese, both laymen and clergy, where in older publications Western Jesuit priests like Van Lith and Prennthaler used to play the leading roles. Barnabas Sarikromo is foremost among the Javanese whose role in, and importance for, the origin and development of Sendangsono as a Roman Catholic pilgrimage place is stressed by the three booklets. The increasing popularity of Barnabas Sarikromo is also visible by the fact that his painted portrait is exhibited in the Muntilan Museum of Mission, which was established in 1998 and opened in 2003, and that a biography was dedicated to his life and work in 2005 (Tartono 2005). Clearly, the Javanese Barnabas Sarikromo was to serve as a role model for the Javenese because of his meritorious services to the Roman Catholic community of Sendangsono, and because he was the first Indonesian who received the papal medal of honour Pro Ecclesia et Pontifice. The Javanese Jesuit priest Albertus Bagus Laksana explains that one of the new emphases in the 'master narrative' of Sendangsono is that Barnabas Sarikromo

is also portrayed as a bridge between the Javanist religion and Catholicism. [...] Sarikrama was both a pilgrim par excellence and a bridge or road that connects the two spiritual worlds at the founding moment of the community. Here one sees the framework of continuation and fulfillment between the two traditions. For Sarikrama took up the spiritual tradition of the Javanese $[. .$.$] seriously as the necessary soil for the incul-$ turation of the Catholic faith..

LAKSANA 2014:115

\section{Romo Mangunwijaya (1929-1999) and the Further Javanization' of Sendangsono}

As well as Barnabas Sarikromo, the name of the Javanese author, architect, and priest Yusuf Bilyarta Mangunwijaya (1929-1999) often crops up, although he is better known to many as Romo Mangun. From 1969, Romo Mangun was actively involved in developing Sendangsono as a place of pilgrimage (Ziarah ke Gua Maria 2010:14-7). His design and layout of the complex gave Sendangsono 
an additional, highly valuable dimension: the place is the three-dimensional solidified ideal of Romo Mangun. As an architect, he based his work on the principle that the interests of the less advantaged should always predominate. As a post-Vatican II priest, he was convinced that, in a religious building, the sanctity of worship and rituals should form a unity with people's day-to-day lives. The sacredness and ritual purity of a religious building should never lead to a person feeling unfit to enter as a result of his sinfulness. Architecture must provide harmony between the world within and the world outside a religious building (Sunaryo 2007:41-5).

In designing and laying out the Sendangsono complex, Romo Mangun was inspired by the traditional Javanese vernacular and palace architecture. On the one hand, this allowed him to harmonize the design with that of the Tri Tunggal Mahakudus chapel, which had been built in 1959 next to the Our Lady of Lourdes grotto. Just like the Javanese joglo house, this chapel had a three-tiered roof, symbolizing the Christian dogma of the Trinity. On the other hand, in this way Romo Mangun was able to recreate the Sendangsono complex as a harmonious unity that was clearly Roman Catholic in character, but breathed a truly Javanese atmosphere and serenity in line with the post-Vatican II ideal of inculturation of the faith. Not only did he build two additional chapels - the Mother Mary or Our Lady chapel and the chapel of the Twelve Apostles-for the celebration of the Eucharist, but also four covered seating areas, where visitors to Sendangsono could rest and relax. In this way, according to Steenbrink (1993:255), Romo Mangun

made this place really an arena for popular religion. Small restaurants, picnic places and the spring with the holy water are the dominant structures, while the altar and the room for the formal liturgy of the Catholic Church has only been given an architectural place somewhere in the 'backyard' of this giant theatre of popular devotion.

Characteristic of Romo Mangun's work is the use of the local beauty of nature, appreciation of which he considered to be part of religiosity (Tjahjono 1995: 152), and natural and locally available building materials, as a result of which the Sendangsono complex forms a unity with its environment. This ecological building method of integrating nature and religion won Romo Mangun a prestigious architectural prize in 1991 (Sunaryo 2007:45). Admiring Romo Mangun's work thus became one of the reasons-in addition to all the other ones- to visit Sendangsono.

Romo Mangunwijaya succeeded in remodelling the complex of Sendangsono into a ritual space (Siswanto 1995:222), where its visitors could experi- 
ence harmony, both among themselves (Jav./Ind. rukun) and between mankind and nature (Jav./Ind. selaras) (Magnis-Suseno 1981:62-5; Koentjaraningrat 1985: 455). The importance of these highly esteemed values was made clear to me in an interview with the six young people, three boys and three girls, I met at the taps where the pilgrims drink and collect water from the original spring of Sendangsono. They had come to Sendangsono by moped from Muntilan, Father Van Lith's parish. The youngsters confided to me that - given their age-none of them were allowed to ride a moped, but it was the only way for them to get to Sendangsono. For them, Sendangsono was an agreeable Sunday outing, because their Roman Catholic parents never objected to them visiting this place of pilgrimage, the cradle of Roman Catholicism on Central Java. They enjoyed being together in a calm atmosphere and to relax far from their parents' watchful eyes. However, they stated that the most important reason for their visit was that they felt Sendangsono was one of the few places left in Central Java where one could experience the 'real' Javanese cultural values of harmony with both mankind and nature.

\section{Concluding Reflections}

The motive of the six youngsters' visit to Sendangsono to experience 'real' Javanese cultural values brings me back to the central question of this contribution: what can be said about the Central Javanese cultural values of the Special Region of Yogyakarta when perceived through the lens of the pilgrimage site at Sendangsono?

The 'master narrative' shows that Van Lith tried to win over the predominantly Muslim population of Central Java to Roman Catholic Christianity by means of an adaptation strategy. He worked with religious perceptions and ritual practices focused on Mary which, in his opinion, linked up with the religious and cultural lives of the inhabitants of Central Java. In that way, he effected a 'Javanization of Catholicism', which led to 'a spiritual identity broader than just Catholicism, and even than monotheism', thus enabling the inculturation of 'Christianity in local spiritual cultures' (Madinier 2011:43). Prennthaler continued Van Lith's adaptation strategy, but added a 'Western touch' by building a typically Western-style Our Lady of Lourdes grotto and siting Angelus bells there. After Prennthaler's death, this policy was continued with the building of the church of Promasan and the Way of the Cross, both totally nonJavanese in character.

The 1959 Tri Tunggal Mahakudus chapel heralded the further Javanization of Sendangsono. In the process of further Javanization the catechist Barnabas 
Sarikromo plays a much more prominent part than he ever did earlier in the 'master narrative'. In addition to Barnabas Sarikromo, the role of Yusuf Bilyarta Mangunwijaya was highlighted. With his redesign and renewed layout of Sendangsono, he made the pilgrimage site-perhaps nolens volens-a place where the people of Central Java again experience their 'shared sacred space' full of hospitality (Laksana 2015:110) and harmony. They rediscover Sendangsono as a holy place for all Javanese, because-in Maria Couroucli's words - it is a place with a 'long tradition of cultural pluralism characterized by the coexistence of more than one symbolic system within a relatively loosely organized society, a social order maintained for centuries over vast territories' (Couroucli 2012:45).

Thanks to Romo Mangun's efforts, Sendangsono again reflects the structure of Javanese society (Laksana 2014:170). This explains why the Our Lady of Lourdes pilgrimage site is not only visited by Roman Catholics, but also by Protestants, Muslims, Hindus, and believers of other persuasions from Central Java: they all celebrate their 'Javanese culture as the Common Bond' there (Laksana 2014:195). Here, they can share their feeling (Jav./Ind. rasa) of 'Javaneseness'; here, despite differences in religion and faith, 'personal, communal, social and spiritual harmony', will not be undermined (compare with Seise 2017:10, 101). Through the lens of the Marian pilgrimage site of Sendangsono, it becomes clear that the people of Central Java from the Special Region of Yogyakarta seem to find the shared feeling of solidarity, social and cosmic harmony, hospitality, and mutuality a more important characteristic of their culture than a belief in Mary, who bears similarities to Maryam, Dewi Lantamsari, and Dewi Sri.

\section{References}

85 tempat ziarah (2013). 85 tempat ziarah gua Maria se Nusantara. Yogyakarta: Chivita Books.

Antono, Y.S. (2011). Ziarah dalam perspektif sosiologi. Studi keagamaan populer di keuskupan agung Semarang. Unpublished Ph.D. thesis, Universitas Indonesia (Departemen Sosiologi), Depok.

Appel, M. (1991). Dewi Sri und die Kinder des Putut Jantaka: Beziehungen zwischen Mensch und Reis in Mythologie und Brauchtum aufJava und Bali. München: Anacon Verlag.

Beck, H.L. (1995). 'Onze Lieve Vrouwe van Sendangsono: Een Indonesische Mariabedevaartplaats door moslimse ogen', in: M. van Uden, J. Pieper and P. Post (eds): Oude sporen, nieuwe wegen: Ontwikkelingen in bedevaartonderzoek, pp. 203-31. Baarn: Gooi en Sticht. 
Beck, H.L. (2015). 'Sendangsono Revisited: Central Java through the Lens of a Marian Pilgrimage Site', in: L. Sparks and P. Post (eds): The Study of Culture Through the Lens of Ritual, pp. 229-43. Amsterdam: Institute for Ritual and Liturgical Studies, Protestant Theological University and Groningen: Institute for Christian Cultural Heritage, University of Groningen.

Beinert, W. and H. Petri (eds) (1984). Handbuch der Marienkunde. Regensburg: Pustet. Boelaars, Y. (1984). Kepribadian Indonesia modern: Suatu penelitian antropologi budaya. Jakarta: Gramedia.

Boelaars, H.J.W.M. (1991). Indonesianisasi: Het omvormingsproces van de katholieke kerk in Indonesië tot de Indonesische katholieke kerk. Kampen: J.H. Kok. [PhD thesis Tilburg University.]

Couroucli, M. (2012). 'Chthonian spirits and shared shrines: The dynamics of place among Christians and Muslims in Anatolia', in: G. Bowman (ed.), Sharing the sacra: The politics and pragmatics of intercommunal relations around holy places, pp. 446o. New York and Oxford: Berghahn Books.

Courtens, I. (2009). 'Mary, mother of all: Finding faith at the sacred source of Sendangsono, Indonesia', in: A.-K. Hermkens, W. Jansen and C. Notermans (eds), Moved by Mary: The power of pilgrimage in the modern world, pp. 101-15. Surrey and Burlington: Ashgate.

Fanani, S. (1985). 'Sendangsono (sebagai tempat ziarah umat Katholik)'. Unpublished MA thesis, IAIN Sunan Kalijaga, Yogyakarta.

Heuken, A. (1989). Ensiklopedi populer tentang Gereja Katolik di Indonesia. Jakarta: Yayasan Cipta Loka Caraka.

Koentjaraningrat (1985). Javanese culture. Singapore etc.: Oxford University Publishers.

Kruijt, A.C. (1906). Het animisme in den Indischen archipel. 's-Gravenhage: Nijhoff.

Kruithof, M.J. (2014). 'Shouting in a desert': Dutch missionary encounters with Javanese Islam 1850-1910. PhD thesis, Erasmus University, Rotterdam.

Laksana, A.B. (2014). Muslim and Catholic pilgrimage practices: Explorations through Java. Surrey and Burlington: Ashgate.

Laksana, A.B. (2015). 'Back-and-forth riting: The dynamics of Christian-Muslim encounters in shrine rituals', in: M. Moyaert and J. Geldhof (eds), Ritual participation and interreligious dialogue: Boundaries, transgressions and innovations, pp. 109-21 and 232-4. London etc.: Bloomsbury.

Lith, F. van (1930). 'Mijn eerste bezoek aan Kalibawang. Uit nagelaten aanteekeningen van Råmå F. van Lith S.J., Z.G.', St. Claverbond 42:255-61 and 283-99.

Madinier, R. (2011). 'The Catholic politics of inclusiveness: A Jesuit epic in Central Java in the early twentieth century and its memory', in: M. Picard and R. Madinier (eds), The politics of religion in Indonesia: Syncretism, orthodoxy, and religious contention in Java and Bali, pp. 23-47. London and New York: Routledge. 
Magnis-Suseno, F. (1981): Javanische Weisheit und Ethik: Studien zu einer östlichen Moral. München, Wien: Oldenbourg.

Rijckevorsel s.J., L. van (1952). Pastoor F.van Lith s.J.:De stichtervan de missie in MiddenJava 1863-1926. Nijmegen: Stichting St. Claverbond.

Roest Crollius S.J., A.A. (ed.) (1984). What is so new about inculturation? Series Inculturation. Working papers on Living Faith and Cultures. Rome: V. Pontifical Gregorian University.

Rood s.J., L. (1930). 'De Angelus-klokjes in Kalibawang', St. Claverbond 42:121-6.

Rzepkowski, H. (1991). 'Indonesien', in: R. Bäumer and L. Scheffczyk (eds), Marienlexikon, Band III, p. 301 . St. Ottilien: Eos Verlag.

Seise, C. (2017). Religioscapes in Muslim Indonesia. Personalities, institutions and practices. Berlin: Regiospectra.

Sindhunata S.J., G.P. (ed.) (2004). Mengasih Maria. 100 tahun Sendangsono. Yogyakarta: Penerbit Kanisius.

Siswanto, A. (1995). 'YB. Mangunwijaya: Arsitek wastu citra', in: Abdurrahman Wahid a.o. (eds), Mendidik manusia merdeka. Romo Y.B. Mangunwijaya 65 tahun, pp. 20948 Yogyakarta: Interfidei and Pustaka Pelajar.

Soeradjiman, P. (1976). Sendangsono. Promasan Kalibawang 8 Desember 1929. Magelang: Putra Bhakti.

Steenbrink, K.A. (1993). 'The rehabilitation of the indigenous. A survey of recent research on the history of Christianity in Indonesia', Exchange 22-3:250-63.

Steenbrink, K. (2007). Catholics in Indonesia: A documented history, 1808-1942. Vol. 2: The spectacular growth of a self-confident minority, 1903-1942. Leiden: KIT LV Press.

Sunaryo, R.G. (2007). 'Mengikuti langkah pikir Romo Mangun: Sebuah tinjauan mengenai metode perancangan arsitektur Yusuf Bilyarta Mangunwijaya', Dimensi Teknik Arsitektur 35-1 (July):41-5.

Suparyanto (1990). 'Makna dan fungsi patung Ibunda Maria dalam agama Katolik Romawi (studi kasus di Gua Lourdes Sendangsono Kalibawang)'. Unpublished MA thesis, IAIN Sunan Kalijaga, Yogyakarta.

Sutarman, P.S. (1990). Sadrach's community and its contextual roots: A nineteenth century Javanese expression of Christianity. Amsterdam-Atlanta: Rodopi.

Tartono, St. S. (2005). Barnabas Sarikrama. Orang Indonesia pertama penerima bintang kepausan. Muntilan: Museum Misi Muntilan and Yogyakarta: Yayasan Pusaka Nusantara.

Tennekes, J. (1986). Volkskatholicisme in Latijns-Amerika. Amsterdam: vu Uitgeverij. Tjahjono, G. (1995): 'Penghayatan dan tindakan: Suatu renungan terhadap karya arsitektur Mangunwijaya', in: Abdurrahman Wahid a.o. (eds), Mendidik manusia merdeka. Romo Y.B. Mangunwijaya 65 tahun, pp. 145-66. Yogyakarta: Interfidei and Pustaka Pelajar.

Vriens S.J., G. (1930a). 'O.L. Vrouw van Kalibawang en een 25-jarig jubilé', St. Claverbond 42:97-119. 
Vriens s.J., G. (193ob). 'Nogmaals de processie van Kalibawang', St. Claverbond 42:232-8.

Ziarah ke Gua Maria (2010). Ziarah ke Gua Maria Lourdes Sendangsono. Yogyakarta: Pitulast Production. 